\title{
Characterization of a New Variant of Human Red Cell Carbonic Anhydrase I, CA If London (Glu-102 $\rightarrow$ Lys)
}

\author{
N. D. Carter, ${ }^{1}$ R. J. Tanis, ${ }^{2}$ R. E. Tashian, ${ }^{2}$ and R. E. Ferrell ${ }^{2}$
}

Received 20 June 1973-Final 11 July 1973

A new inherited variant of red cell carbonic anhydrase $I(C A I)$, designated $C A$ If London, was discovered during a survey of 1615 individuals from London, England. No electrophoretic variants of the other isozyme of carbonic anhydrase $C A I I$, were observed in the same survey. Sequence analysis of a lysine-blocked tryptic peptide believed to contain the amino acid substitution in $C A$ If showed that the glutamyl residue at position 102 had been substituted by a lysyl residue. This substitution results in a net increase of two positive charges in the mutant enzyme. Densitometric scanning of the electrophoretically separated forms in the variant hemolysate indicates that the levels of the normal and variant enzymes are approximately equal.

\section{INTRODUCTION}

Previous studies have shown that inherited electrophoretic variants of the low-activity isozyme of red cell carbonic anhydrase, CA I (or CA B), occur with low frequencies in most human populations ( $c f$. Carter et al., 1972). In contrast, only one variant of the high-activity isozyme, CA II (or CA C), has as yet been reported, and this was found to be polymorphic in the U.S. Negro population (Moore et al., 1971, 1973).

This communication describes the chemical characterization of a new

Supported in part by U.S. Public Health Service grant GM15,419.

${ }^{1}$ Department of Biochemistry, London Hospital Medical College, London, England.

${ }^{2}$ Department of Human Genetics, University of Michigan Medical School, Ann Arbor, Michigan. 
electrophoretic variant of CA I which was discovered in a healthy, adult male of English extraction during a survey of 1615 individuals from London, England. The variant CA I, designated CA If London, was also found in the son and daughter of the propositus; his wife showed the normal CA I phenotype. Previously, two other variants of CA I, CA Ie Hull and CA Ie Portsmouth, were reported from a survey of 8500 individuals from the English population (Carter et al., 1972).

\section{MATERIALS AND METHODS}

Electrophoretic Techniques

For the survey, electrophoresis was carried out at room temperature on Cellogel strips using a $0.12 \mathrm{M}$ tris-0.05 м EDTA-0.015 м borate buffer $(p \mathrm{H} \mathrm{9.1)}$ for $2 \mathrm{hr}$ at $400 \mathrm{v}$ as previously described (Carter et al., 1972). The gels were stained for protein with nigrosin, and bromthymol blue was used to locate the zone of $\mathrm{CO}_{2}$ hydrase activity (Tashian, 1969). For comparative purposes, starch gel electrophoresis of CA If was also carried out using a borate buffer system at $p \mathrm{H} 8.6$ (Tashian, 1969).

\section{Quantitative Techniques}

A radioimmunosorbent assay which is specific for carbonic anhydrase I was used to determine the level of CA I in hemolysates. The assay was performed according to the method of Magid et al. (1973).

The nigrosin-stained Cellogel strips were scanned for intensity with a Joyce-Loebl scanner using reflected light from a green filter.

\section{Isolation of the Variant Enzyme}

About $400 \mathrm{ml}$ of blood from the propositus was collected into acid-citratedextrose (ACD). Hemoglobin was precipitated with a chloroform-ethanolwater mixture, and the variant enzyme was separated by DEAE-cellulose (DE52, Whatman) column chromatography using a system similar to that described by Carter et al. (1972) except that $0.005 \mathrm{~m}$ tris- $\mathrm{HCl}(p \mathrm{H} \mathrm{8.6)}$ was used to preferentially elute the variant enzyme. The normal CA I and CA II isozymes were sequentially eluted by increasing the buffer concentration to $0.1 \mathrm{M}$, employing either an exponential or a linear gradient.

\section{Peptide Analysis}

Tryptic digestion was carried out as previously described for the CA Ie Hull and CA Ie Portsmouth variants (Carter et al., 1972), and chymotryptic 
digestion by the method of Shows (1967). One-dimensional electrophoretic separation of the peptides was carried out in a pyridine-acetate buffer ( $p$ H 6.5) for $3 \mathrm{hr}$ at $3000 \mathrm{v}$. Guide strips were cut out, and the peptides were eluted with either $6 \mathrm{~N} \mathrm{HCl}$ or $1 \mathrm{M}$ acetic acid. Amino acid analysis was performed on peptides which had been hydrolyzed for $16 \mathrm{hr}$ in $\mathrm{N} \mathrm{HCl}$ at $110 \mathrm{C}$.

\section{Sequence Analysis}

In order to determine the exact position of the amino acid substitution in CA If London, techniques were used which were effective in isolating the peptide which contained the amino acid substitution in CA Id Michigan (cf. Tanis et al., 1973). Approximately $20 \mathrm{mg}$ of purified CA If was treated with an excess of citraconic anhydride to mask quantitatively the $\varepsilon-\mathrm{NH}_{3}$ groups of the lysine residues. Following removal of excess reagent, the modified enzyme was treated with trypsin and then fractionated on a G150 column equilibrated with $0.05 \mathrm{M}$ N-ethyl morpholine $(p \mathrm{H} \mathrm{8.2)}$.

The peptide, isolated from the above column, was sequenced directly using the Beckman automatic sequencer (model 890). The hydantoin derivatives were analyzed by gas chromatography, and by amino acid analysis (after treating with $5 \mathrm{~N} \mathrm{HI}$ at $140 \mathrm{C}$ for $24 \mathrm{~h}$ ).

\section{Enzyme Assays}

$\mathrm{CO}_{2}$ hydrase activity was measured by using the bromthymol blue assay as originally described by Wilbur and Anderson (1948). The concentration of CA I was calculated by the absorbance at $280 \mathrm{~nm}\left(\mathrm{~A}_{280}\right)$ by assuming 1.63 for a $1 \mathrm{mg} / \mathrm{ml}$ solution (Armstrong et al., 1966). Enzyme units were calculated from $\left(T_{0}-T\right) / T$, where $T_{0}$ is the reaction time for the uncatalyzed reaction and $T$ represents the time interval for the catalyzed reaction. The carboxylic esterase activity was measured at $30 \mathrm{C}$ by using the substrate $p$-nitrophenyl acetate in phosphate buffer at $p \mathrm{H} \mathrm{6.8}$. The activity was related to protein concentration using molar absorbances quoted by Armstrong et al. (1966) for p-nitrophenol.

\section{RESULTS}

The Survey

After protein staining of the Cellogel strips for the 1615 hemolysates from the London population, the electrophoretic patterns of CA I and CA II were found to be qualitatively identical, with the exception of one pattern which is shown in Fig. 1. The electrophoretic patterns for the normal CA I 


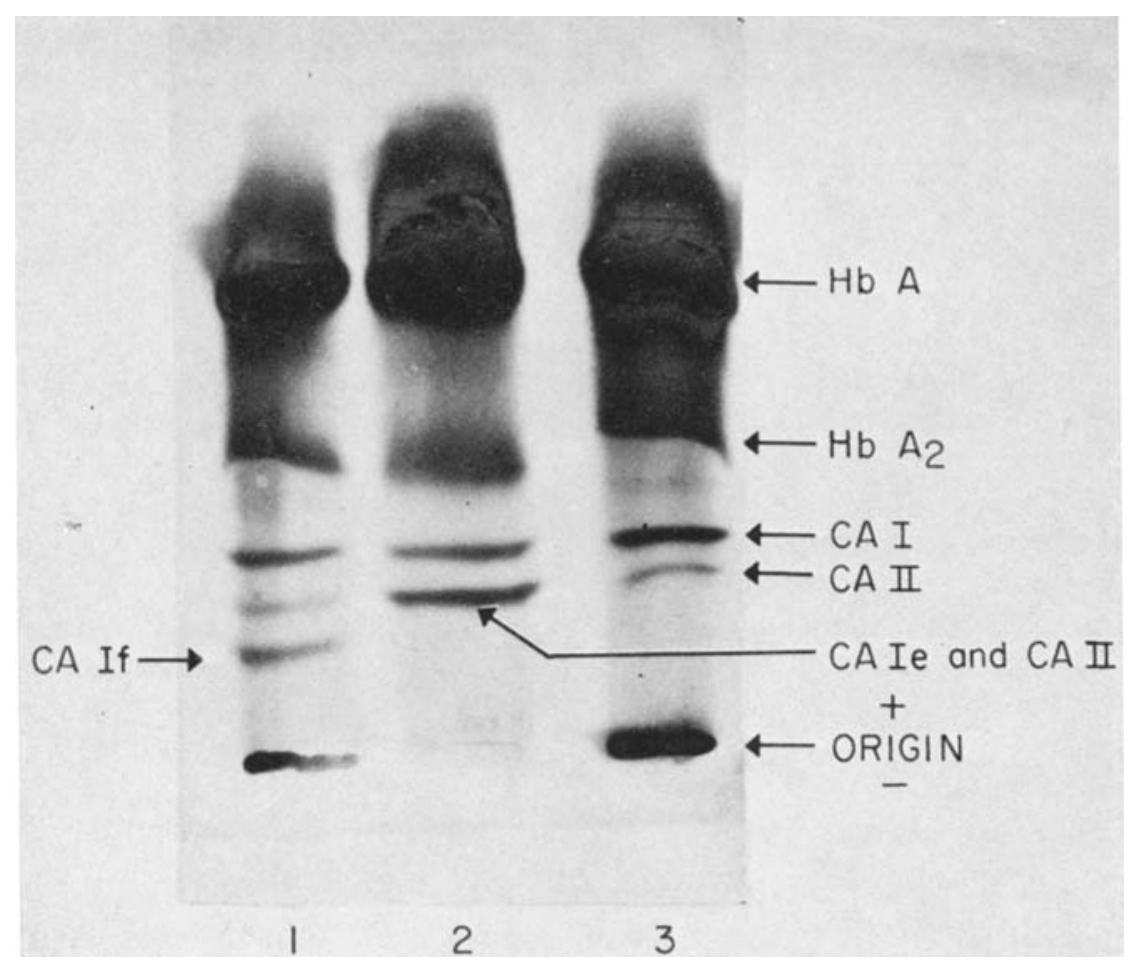

Fig. 1. Typical protein stain (nigrosin) patterns of normal and variant hemolysates after electrophoresis (room temperature) on Cellogel strips for $2 \mathrm{hr}$ at $400 \mathrm{v}, p \mathrm{H} \mathrm{9.1.} \mathrm{(1)} \mathrm{CA} \mathrm{If}$ London, (2) CA Ie Hull, (3) CA I normal.

phenotype and CA Ie Hull are shown for comparison. The starch gel electrophoresis patterns of the same normal and variant carbonic anhydrases (after hemoglobin extraction) are shown in Fig. 2. Examination of the altered pattern indicated that the individual was heterozygous for a variant of CA I in which the mutation had resulted in an increased positive charge. Since the electrophoretic migration of CA Ie Hull was shown to be due to the increase of a single positive charge, i.e., Gln $\rightarrow$ Lys/Arg (Carter et al., 1972), it can be assumed that because CA If London has migrated approximately twice the distance of CA Ie Hull toward the cathode that its overall charge has increased by two positive charges.

\section{Purification}

Two-hundred-milliliter aliquots of saline-washed red cells were extracted 


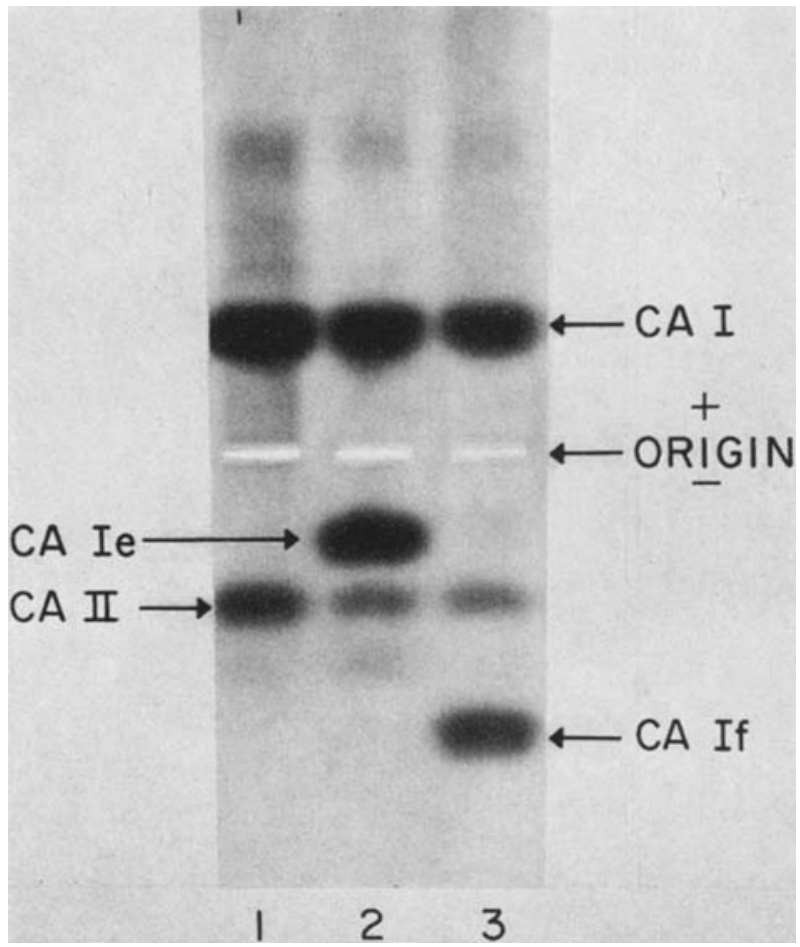

Fig. 2. Protein stain (nigrosin) patterns of normal and variant carbonic anhydrases after extraction of hemoglobin (see text) and starch gel electrophoresis $(4 \mathrm{C})$ for $18 \mathrm{hr}$ at $8 \mathrm{v} / \mathrm{cm}, p \mathrm{H} \mathrm{8.6.} \mathrm{(1)}$ Normal CA I, (2) CA Ie Hull, (3) CA If London.

with chloroform-ethanol-water as previously described (vide supra). Purified CA If enzyme was eluted from the DE52 column with $0.005 \mathrm{M}$ tris- $\mathrm{HCl}$ buffer $(p \mathrm{H} 8.6)$; other proteins from the extract remained bound. The homogeneity of a typical preparation is shown in the electrophoretic pattern in Fig. 3. By this method, about $50 \mathrm{mg}$ of CA If was isolated for further study.

\section{Estimation of CA I and CA If Levels}

A reflectance scan of a protein-stained Cellogel strip after electrophoresis of a hemolysate containing the normal and variant carbonic anhydrases is shown in Fig. 4. As can be seen, the quantities of CA I and CA If appear to be about equal.

The total amount of CA I (normal plus variant) in the variant hemolysate 


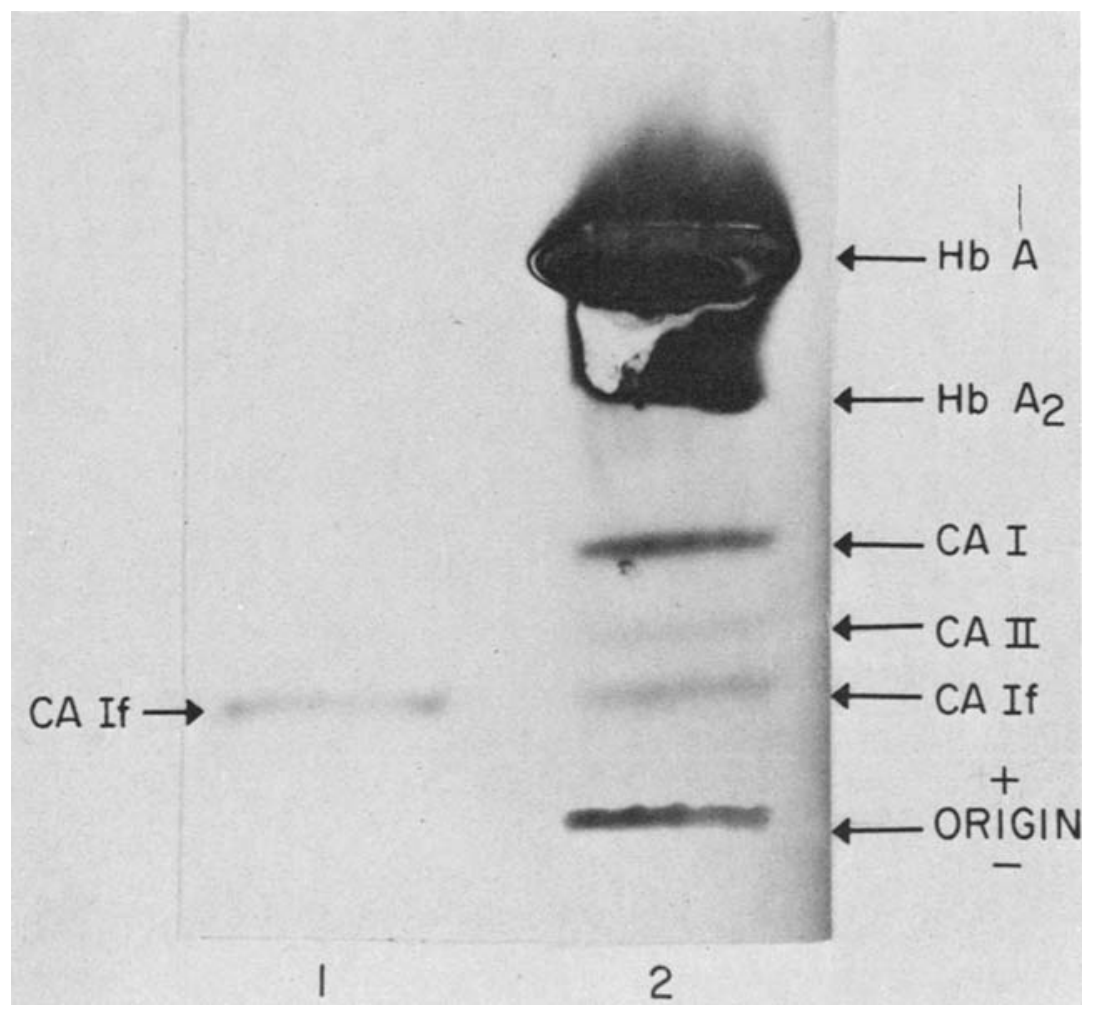

Fig. 3. Protein stain patterns after electrophoresis on Cellogel (see Fig. 1) demonstrating purification of CA If variant. (1) Purified CA If London, (2) hemolysate containing CA If London.

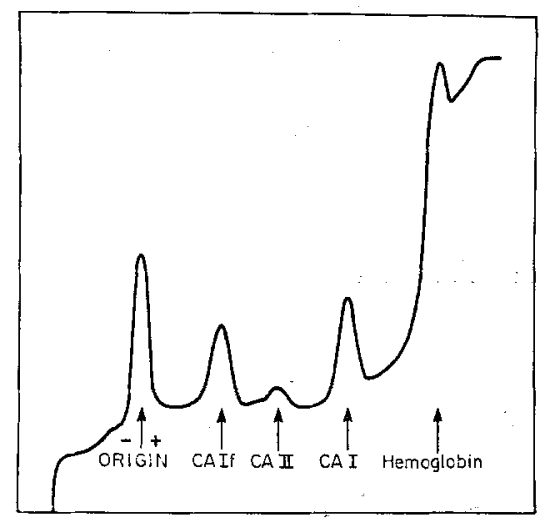

Fig. 4. Reflectance scan of protein-stained Cellogel strip after electrophoresis of hemolysate containing $\mathrm{CA} I$ and $\mathrm{CA}$ If. See Fig. 1 for staining pattern. 
was found to be $12.9 \mu \mathrm{g} / \mathrm{mg}$ hemoglobin by the radioimmunosorbent assay (Magid et al., 1973). This value is close to the mean of $12.0 \mu \mathrm{g} / \mathrm{mg} \mathrm{Hb}$ (range $5.9-16.5 \mu \mathrm{g} / \mathrm{mg} \mathrm{Hb}$ ) found in a survey of 72 normal, adult, U.S. Caucasians (R. E. Tashian, unpublished results).

\section{Enzyme Activity}

Esterase activity and $\mathrm{CO}_{2}$ hydrase activities were measured, and the results are summarized in Table I. Essentially no differences were observed between the specific activities of the normal and variant enzymes.

\section{Peptide Studies}

Three milligrams of normal CA I and the variant CA If were digested with trypsin, and peptide maps were prepared. One new tryptic spot was observed. This spot was eluted from a peptide map (lightly sprayed with ninhydrin) with $6 \mathrm{~N} \mathrm{HCl}$ and analyzed following hydrolysis at $110 \mathrm{C}$ for $16 \mathrm{hr}$. The analysis suggested that this peptide represented the region from His-103 to Lys-113, based on the human CA I sequence data of Anderson et al. (1972), Laurent-Tabusse et al. (1972), and Lin and Deutsch (1973). The core material obtained from the tryptic digestion of $6 \mathrm{mg}$ of CA I and CA If was washed with water and digested with chymotrypsin. One-dimensional electrophoresis of this material revealed one additional peptide in the CA If core. Amino acid analysis of this peptide indicated that it represented the region from Gly98 to Glu-102 except that the $C$-terminal glutamic acid residue had been substituted by a lysine residue.

\section{Confirmation of the Amino Acid Substitution}

Lysine-blocked CA If material was trypsinized and fractionated on a G150

Table I. Enzyme Activities of Normal (CA I) and Variant (CA If) Carbonic Anhydrases

\begin{tabular}{|c|c|c|}
\hline CA I types & $\begin{array}{c}\mathrm{CO}_{2} \text { hydrase activity }{ }^{a} \\
\text { (units } / \mathrm{mg} \text { ) }\end{array}$ & $\begin{array}{c}\text { Esterase activity } \\
(p \text {-nitrophenol acetate) } \\
\text { (units } / \mathrm{mg})\end{array}$ \\
\hline CA I & 5.0 & 0.51 \\
\hline $\mathrm{CA}$ If & 5.0 & 0.49 \\
\hline
\end{tabular}

${ }^{a}$ Twenty microliters of enzyme used in assay mixture.

${ }^{b}\left(T_{0}-T\right) / T$ (see text).

c Micromoles $p$-nitrophenol formed/min. 


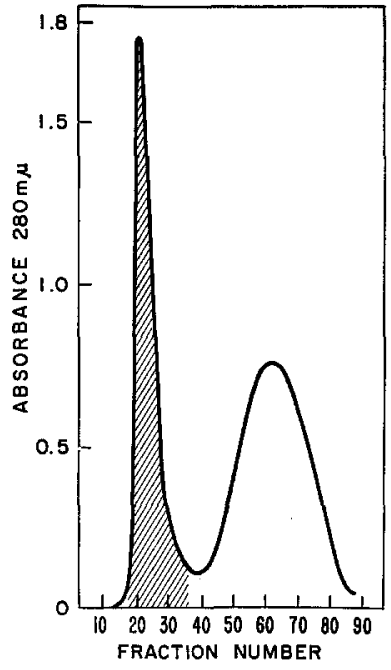

Fig. 5. Elution profile of a lysine-blocked tryptic digest of CA If London. A 1.5- by 90-cm Sephadex G150 column equilibrated with $0.05 \mathrm{M} N$-ethyl morpholine $(p \mathrm{H} \mathrm{8.2)}$ was used. Approximately 1.2-ml fractions were collected. The shaded area (fractions 18-37) represents the peptide beginning at Leu 90 , and this was pooled for sequence studies (see text).

Table II. Identification of the PTH Derivatives from Sequence Analysis of Normal (CA I) and Variant (CA If) Lysine-Blocked Tryptic Peptides Isolated by Column Chromatography

\begin{tabular}{|c|c|c|c|c|}
\hline \multirow[t]{2}{*}{$\begin{array}{l}\text { Position of } \\
\text { residue in CA I } \\
\text { sequence }\end{array}$} & \multirow[t]{2}{*}{$\begin{array}{l}\text { Sequencer } \\
\text { step }\end{array}$} & \multicolumn{2}{|c|}{$\begin{array}{c}\text { Derivatives } \\
\text { identified by } \\
\text { gas chromatography }\end{array}$} & \multirow{2}{*}{$\begin{array}{c}\begin{array}{c}\text { Derivatives } \\
\text { identified with } \\
\text { amino acid analyzer }\end{array} \\
\text { CA If }\end{array}$} \\
\hline & & $\mathrm{CA} \mathrm{I}^{a}$ & CA If & \\
\hline 90 & 1 & Leu & Leu & Leu \\
\hline 91 & 2 & Phe & Phe & Phe \\
\hline 92 & 3 & Gln & Gln & - \\
\hline 93 & 4 & Phe & Phe & - \\
\hline 94 & 5 & His & His & - \\
\hline 95 & 6 & Phe & Phe & - \\
\hline 96 & 7 & His & His & - \\
\hline 97 & 8 & Trp & Trp & - \\
\hline 98 & 9 & Gly & Gly & - \\
\hline 99 & 10 & Ser & Ser & Ser \\
\hline 100 & 11 & Thr & Thr & Thr \\
\hline 101 & 12 & Asn & Asn & Asx \\
\hline 102 & 13 & Glu & Lys & Lys \\
\hline 103 & 14 & His & His & His \\
\hline
\end{tabular}

a Data taken from Tanis et al. (1973). 
Sephadex column. The elution profile obtained is shown in Fig. 5. Results of previous study (Tanis et al., 1973) had shown that the peptide beginning at Leu-90 was located in the first peak; therefore, fractions $18-37$ were pooled and concentrated by nitrogen blowdown. The peptide material, insoluble as a result of the concentration procedure, was used directly for sequence determination. No major contaminating peptides were observed with these procedures.

The gas chromatography and amino acid analysis data resulting from the sequencer analysis are presented in Table II. As can be seen, the presumed Glu-102 $\rightarrow$ Lys substitution occurs at step 13 (position 102 in the human CA I sequence). Furthermore, the presence of lysine at step 13 was confirmed by regenerating the PTH-free amino acid and carrying out standard amino acid analysis.

\section{DISCUSSION}

With the discovery of CA If London, the frequency of inherited variants of CA $I$ in the British population is now 3/10,115 individuals [i.e., 1/1615 (this study) plus 2/8500 (Carter et al., 1972)]. In contrast, no variant of the high-activity isozyme, CA II, was found in the same two surveys.

This is the first variant of human CA I in which the overall charge has increased by two positive charges. The presumed single amino acid substitutions in all of the eight other variants of CA I (CA Ib Michigan, CA Ic Guam, CA Ic Filipino, CA Ie Michigan, CA Ie Hull, CA Ie Portsmouth, CA Id Michigan, and CA P Mut) appear to show an increase of one positive charge (cf. Fig. 4 in Carter et al., 1972, and Fig. 5 in Funakoshi and Deutsch, 1970).

The amino acid substitution in CA If London (Glu-102 $\rightarrow$ Lys) is located only two residues from the substitution found in CA Id Michigan (Thr-100 $\rightarrow$ Lys). If the tertiary structure of CA I is similar to the known high-resolution, three-dimensional structure of human CA II (Liljas et al., 1972), then we would expect positions 100 and 102 to be on the surface of the CA I molecule. It is of interest that despite the close proximity of these substitutions, and the fact that a lysyl residue has been substituted in both cases, the quantitative effects appear to be different. That is, the amount of CA Id in the variant hemolysate seems to be lower than the normal CA I (Shows, 1967), whereas in the CA If hemolysate the levels of the normal and variant enzymes appear to be present in approximately equal amounts.

\section{ACKNOWLEDGMENTS}

This work was carried out with the expert technical assistance of Mrs. Sharon R. Stroup, Mrs. Ya-Shiou L. Yu, and Mr. Bernard Mulligan. 


\section{REFERENCES}

Andersson, B., Nyman, P. O., and Strid, L. (1972). Amino acid sequence of human erythrocyte carbonic anhydrase B. Biochem. Biophys. Res. Commun. 48:670.

Armstrong, J. McD., Myers, D. V., Verpoorte, J. A., and Edsall, J. T. (1966). Purification and properties of human erythrocyte carbonic anhydrases. J. Biol. Chem. 241:5137.

Carter, N. D., Tashian, R. E., Huntsman, R. G., and Sacker, L. (1972). Characterization of two new variants of red cell carbonic anhydrase in the British population: CA Ie Portsmouth and CA Ie Hull. Am. J. Hum. Genet. 24:330.

Funakoshi, S., and Deutsch, H. F. (1970). Human carbonic anhydrases. IV. Properties of a mutant B type isozyme. J. Biol. Chem. 245:4913.

Laurent-Tabusse, G., Giraud, N., and Limozin, N. (1972). Structure primaire de l'anhydrase carbonique érythrocytaire B humaine. I. Hydrolyse par la trypsine et séquence des peptides trypsiques. Biochimie 54:809.

Liljas, A., Kannan, K. K., Bergstén, P.-C., Waara, I., Fridborg, K., Strandberg, B., Carlbom, U., Järup, L., Lövgren, S., and Petef, M. (1972). Crystal structure of human carbonic anhydrase C. Nature New Biol. 235:131.

Lin, K.-T. D., and Deutsch, H. F. (1973). Human carbonic anhydrases. XI. The complete primary structure of carbonic anhydrase B. J. Biol. Chem. 248:1885.

Magid, E., DeSimone, J., and Tashian, R. E. (1973). Genetic variation in the carbonic anhydrase isozymes of macaque monkeys. I. The radioimmunosorbent assay. Biochem. Genet. 8:157.

Moore, M. J., Funakoshi, S., and Deutsch, H. F. (1971). Human carbonic anhydrases. VII. A new C type isozyme in erythrocytes of American Negroes. Biochem. Genet. 5:497.

Moore, M. J., Deutsch, H. F., and Ellis, F. R. (1973). Human carbonic anhydrases. IX. Inheritance of variant erythrocyte forms. Am. J. Hum. Genet. 25:29.

Shows, T. B. (1967). The amino acid substitution and some chemical properties of a variant human erythrocyte carbonic anhydrase: Carbonic anhydrase Id Michigan. Biochem. Genet. 1:171.

Tanis, R. J., Ferrell, R. E., and Tashian, R. E. (1973). Substitution of lysine for threonine at position 100 in human carbonic anhydrase Id Michigan. Biochem. Biophys. Res. Commun. $51: 699$.

Tashian, R. E. (1969). The esterases and carbonic anhydrases of human erythrocytes. In Yunis, J. J. (ed.), Biochemical Methods in Red Cell Genetics, Academic Press, New York, p. 307.

Wilbur, K. M., and Anderson, N. G. (1948). Electrometric and colorimetric determination of carbonic anhydrase. J. Biol. Chem. 176:147. 